\title{
IMPLIKASI JUDICIAL REVIEW TERHADAP HAK ANGKET YANG DIAJUKAN OLEH DPR PASCA PUTUSAN MK NO.26/PUU-XVI/2017 TENTANG PERMOHONAN HAK ANGKET DPR
}

\author{
Agnes Fitryantica ${ }^{1}$ \\ Dosen Sekolah Tinggi Ilmu Hukum Iblam \\ Email1:agnesfitryantica@iblam.ac.id \\ DOI: https://doi.org/10.31764/jmk.v11i1.1353
}

Received: Nop 23, 2019, Accepted: Jan 9, 2020 /Published: April 30, 2020

\begin{abstract}
The Constitutional Court based on Article 24C of the 1945 Constitution of the Republic of Indonesia has 4 authorities and 1 obligation. These provisions are further contained in Article 10 of Law Number 24 Year 2003 concerning the Constitutional Court. The constitutional authority of the Constitutional Court in examining, adjudicating and deciding cases of judicial review of the constitution is about the constitutionality of norms. The method used is normative (doctrinal) legal research, using secondary data in the form of primary, tertiary and secondary legal materials. One of the legal materials used as the basis for analysis is the judge's decision and its implications for the judicial review. The results of the study that, the authority to test the Act against the 1945 Constitution theoretically or practically, makes the Constitutional Court as a controlling and balancing body in the administration of state power. The KPK is not the object of the Parlement questionnaire rights. The ruling emphasized that the KPK was an institution that could be the object of the questionnaire right by the Parlement. The implications of the decision of the Constitutional Court Number 36 / PUUXV / 2017, can be grouped in two ways, namely: first, the implications are positively charged, namely the affirmation of the ownership of the House of Representatives questionnaire rights in Indonesian governance. Second, the negative implication is the possibility of using the DPR's excessive questionnaire rights without regard to existing limitations.
\end{abstract}

Keywords : constitutional court; parlement; KPK.

\begin{abstract}
ABSTRAK
Mahkamah Konstitusi berdasarkan Pasal 24C UUD NRI Tahun 1945 memiliki 4 kewenangan dan 1 kewajiban. Ketentuan tersebut dituangkan lebih lanjut dalam Pasal 10 UU Nomor 24 Tahun 2003 tentang Mahkamah Konstitusi. Kewenangan konstitusional Mahkamah Konstitusi dalam memeriksa, mengadili dan memutus perkara pengujian undang-undang terhadap Undang-Undang Dasar adalah mengenai konstitusionalitas norma. Metode yang digunakan adalah penelitian hukum normatif
\end{abstract}


(doktrinal), dengan menggunakan data sekunder berupa bahan hukum primer, tersier dan sekunder. Salah satu bahan hukum yang dijadikan dasar analisis adalah putusan hakim dan implikasinya terhadap yudicial review. Hasil penelitian bahwa, kewenangan menguji Undang-Undang terhadap Undang-Undang Dasar 1945 secara teoritis atau praktis, menjadikan Mahkamah Konstitusi sebagai lembaga pengontrol dan penyeimbang dalam penyelenggaraan kekuasaan negara, Dalam Putusan Nomor 36/PUU-XV/2017, Mahkamah Konstitusi memutuskan menolak permohonan pemohon yang pada intinya menyebut KPK bukan merupakan objek hak angket DPR. Putusan tersebut menegaskan KPK merupakan lembaga yang dapat menjadi objek hak angket oleh DPR. Implikasi dari putusan Mahkamah Konstitusi Nomor 36/PUU-XV/2017 tersebut, dapat dikelompokkan dalam dua hal, yaitu: pertama, implikasi yang bermuatan positif, yaitu penegasan dimilikinya hak angket Dewan Perwakilan Rakyat dalam ketatanegaran Indonesia. Kedua, Implikasi yang bermuatan negatif yaitu adanya kemungkinan penggunaan hak angket DPR yang eksesif tanpa memperhatikan batasan-batasan yang ada.

\section{Kata Kunci: Mahkamah Konstitusi; DPR; KPK.}

\section{PENDAHULUAN}

Salah satu ciri utama dari negara demokrasi yang berdasar atas hukum adalah Constitualism, yang menempatkan konstitusi sebagai hukum dasar atau fundamental, sehingga seluruh praktik penyelenggaraan negara tidak boleh menyimpang dari hukum dasar atau hukum fundamental itu. Konstitusi menjadi landasan kehidupan bernegara dan atau landasan dalam pembentukan peraturan perundangundangan, yang mengatur kekuasaan negara serta hak dan kewajiban warga negara ${ }^{1}$. Dari situ kemudian diturunkan prinsip constitutionaly of law. Artinya, dalam negara demokrasi yang berdasar atas hukum, konstitusi harus senantiasa dijadikan rujukan dalam menilai validitas seluruh praktik penyelenggaraan negara, lebih-lebih dalam pembentukan dan perumusan norma peraturan perundang-undangana, terutama undang-undang. Tanpa itu, maka konstitusi tidak lebih dari sekedar barisan kata-kata yang indah dalam dokumen tetapi dalam praktik tidak

\footnotetext{
${ }^{1}$ Hardjono, Legitimasi Perubahan Konstitusi, Pustaka Pelajar, Yogyakarta, 2009, hal. 27.
} 
terjelma sama sekali. Oleh karena itu, timbul kebutuhan akan adanya institusi yang berfungsi mengawal agar konstitusi benar-benar ditaati dan terjelma dalam kehidupan bernegara sehari-hari. ${ }^{2}$

Dalam praktik ada dua model dalam menerapkan atau mewujudkan gagasan negara demokrasi yang berdasar atas hukum itu, yaitu parliamentary model dan constitutional model. Pada model yang pertama, yang memberlakukan prinsip supremasi parlemen, tidak terdapat kebutuhan untuk membentuk lembaga khusus yang berfungsi mengawal konstitusi sebab parlemen dikonstruksikan sekaligus sebagai pengawal konstitusi. Sementara itu, pada model yang kedua, yang memberlakukan prinsip supremasi konstitusi dimana parlemen justru menjadi bagian dari institusi yang harus diawasi oleh konstitusi, timbul kebutuhan akan perlunya institusi yang berfungsi mengawal konstitusi. Dari sinilah lahirnya gagasan membentuk Mahkamah Konstitusi.

Pembentukan Mahkamah Konstitusi merupakan fenomena baru dalam dunia ketatanegaraan. ${ }^{3}$ Di negara-negara yang tengah mengalami perubahan dari otoritarian menuju demokrasi, gagasan pembentukan Mahkamah Konstitusi dinilai cukup populer. Bahkan, menjadi sesuatu yang urgen karena ingin mengubah atau memperbaiki sistem kehidupan ketatanegaraan lebih ideal dan sempurna, khususnya dalam penyelenggaraan pengujian konstitusional terhadap undang-undang yang bertentangan dengan konstitusi sebagai hukum dan dasar hukum tertinggi negara.

2 I Dewa Gede Palguna, "Mahkamah Konstitusi Dasar Pemikiran, Kewenangan, dan Perbandingan dengan Negara Lain, Konstitusi Press, Jakarta, 2018, hal. 76.

3 Sebenarnya dari segi historis, pemikiran tentang keberadaan lembaga Mahkamah Konstitusi sudah ada sebelum Indonesia merdeka, hal itu terbukti pada saat pembahasan rancangan UUD oleh Badan Penyelidik Usaha-Usaha Persiapan Kemerdekaan Indonesia (BPUPKI), Muh. Yamin sebagai salah satu anggota telah mengusulkan tentang perlunya dibentuk lembaga yang melakukan pengujian Judicial Review konstitusionalitas undang- undang dan diatur dalam UUD. 
Menurut Jimly Asshidiqie, gagasan pembentukan Mahkamah Konstitusi oleh suatu negara umumnya dilatarbelakangi oleh adanya pengalaman pernah mengalami krisis konstitusional dan baru keluar dari sistem pemerintahan yang otoriter. Krisis konstitusional biasanya menyertai perubahan menuju rezim demokrasi, dan dalam proses perubahan itulah Mahkamah Konstitusi dibentuk. ${ }^{4}$

Lebih dari itu, menurut Jimly Asshiddiqie, kehadiran Mahkamah Konstitusi dalam struktur ketatanegaraan Indonesia adalah dalam rangka mewujudkan sistem pemisahan kekuasaan (separation of power) dengan prinsip check and balances..$^{5}$ Selain itu, gagasan pembentukan Mahkamah Konstitusi di Indonesia sendiri menurut Moh. Mahfud MD, dilakukan dalam rangka memperbaiki penegakan hukum di Indonesia melalui reformasi kekuasaan kehakiman. Hal tersebut disebabkan karena banyaknya produk undang-undang yang secara substantif dinilai bertentangan dengan UUD NRI 1945, tetapi tidak ada lembaga atau mekanisme pengujian yang efektif melaui lembaga yudisial (Judicial review). Pada saat itu hanyalah pengujian oleh legislatif (legislative review) dan eksekutif (executive review). Tidak adanya mekanisme kontrol eksternal terhadap kekuasaan pembentukan undang-undang telah membuka peluang bagi penyalahgunaan kekuasaan oleh lembaga pembuat undang-undang untuk menghasilkan undang-undang apa saja, termasuk undang-undang yang bertentangan dengan norma-norma konstitusi sekalipun. ${ }^{6}$

Salah satu substansi perubahan ketiga UUD NRI 1945 yang disahkan dalam sidang tahunan MPR tahun 2001 adalah diperintahkannya untuk membentuk suatu organ atau komponen

\footnotetext{
4 Bachtiar, Problematika Implementasi Putusan Mahkamah Konstitusi pada Pengujian UU terhadap UUD, Raih Asa Sukses, Jakarta, 2015, hal. 74-75.

5 Jimly Asshiddiqie, Pengantar Ilmu Hukum Tata Negara, Konstitusi Press, Jakarta, 2006, hal. 20.

6 Bachtiar, Op.Cit., hal. 85-86.
} 
konstitusi yang dinamakan Mahkamah Konstitusi yang kewenangan dan kewajibannya diatur dalam Pasal 7A, Pasal 7B, Pasal 24C UUD NRI 1945.

Sedangkan kewajibannya adalah memberi putusan atas pendapat DPR mengenai dugaan pelanggaran oleh presiden dan/atau wakil presiden menurut UUD NRI 1945 (Pasal 24C ayat (2)) dan apabila terbukti telah melakukan pelanggaran hukum berupa pengkhianatan terhadap negara, korupsi, penyuapan, tindak pidana berat lainnya, atau perbuatan tercela maupun apabila terbukti tidak lagi memenuhi syarat sebagai presiden dan/atau wakil presiden (Pasal 7A UUD NRI 1945). ${ }^{7}$

Pembentuk UU telah membatasi objek hak angket untuk tidak mencakup objek yang berada diluar ruang lingkup kekuasaan eksekutif, dan layaknya norma ini harus ditaati oleh semua pihak termasuk pembuat UU itu sendiri, dan hakim dalam mengadili perkara konkrit harus tunduk terhadap penafsiran otentik dari norma yang ada.

Banyak yang menilai Hak Angket hanya bisa dilakukan DPR terhadap pemerintah (eksekutif). Sementara, KPK adalah lembaga independen yang tak berada di bawah eksekutif karenanya tak bisa diangket. Ketua KPK Agus Rahardjo pun bereaksi terhadap Pansus. Dia menganggap apa yang dilakukan Pansus menghalangi proses penegakan hukum. Hal itu diyakini bisa menjerat para anggota Pansus KPK ke meja hijau. Agus mengaku KPK mempertimbangkan menjerat anggota Pansus dengan pasal obstruction of justice. ${ }^{8}$

Awal mula bergulirnya polemik hak angket DPR atas KPK berawal dari adanya kasus Miryam S. Hariyani dalam kasus E-KTP pada

7 Abdul Rasyid Thalib, Wewenang Mahkamah Konstitusi dan Implikasinya dalam Sistem Ketatanegaraan Republik Indonesia, PT Citra Aditya Bakti, Bandung, 2006, hal. 288-289.

8 Obstruction of Justice tersebut sebagai berikut: "The noncompliance with the legal system by interfering with (1) the law administration or procedures, (2) not fully disclosing information or falsifying statements, and (3) inflicting damage on an officer, juror or witness.". Terjemahan: Ketidakpatuhan terhadap sistem hukum dengan mengganggu (1) administrasi atau prosedur hukum, (2) tidak sepenuhnya mengungkapkan informasi atau pernyataan yang memalsukan, dan (3) menimbulkan kerusakan pada petugas, juri atau saksi. Lihat, url: https://thelawdictionary.org/obstruction-ofjustice/, diakes tgl 23 April 2019. 
tahun 2017. Dimana pada saat itu DPR meminta rekaman BAP kasus kepada KPK, namun KPK tidak memberikan dengan alasan perkara tersebut sedang ditangani dan untuk menjaga independensi suatu perkara maka rekaman tidak bisa diperlihatkan kepada pihak lain. Masuknya KPK dalam ranah hak angket DPR menjadi pro kontra hingga saat ini. Isu hukum yang muncul berupa ketentuan Undang-Undang No. 24 tahun 2003 tentang Mahkamah Konstitusi dalam kewenangan judicial review undang-undang terhadap UUD NRI 1945, dan implikasi judicial review terhadap Hak Angket yang diajukan oleh DPR pasca Putusan Nomor 36/PUU-XVI/ 2017 tentang Permohonan Hak Angket DPR.

\section{METODOLOGI}

Metode yang digunakan adalah penelitian hukum normatif (doktrinal), dengan menggunakan data sekunder berupa bahan hukum primer, tersier dan sekunder. Salah satu bahan hukum yang dijadikan dasar analisis adalah putusan hakim dan implikasinya terhadap yudicial review. Sifat penelitian normatif deskriptif analitis yaitu penelitian yang bertujuan memberi gambaran dan analisis terhadap permasalahan yang diangkat.

\section{PEMBAHASAN}

\section{A. Produk Hukum dari Judicial Review}

Pengujian UU terhadap UUD 1945 merupakan suatu bentuk pengujian materi dari undang-undang yang diajukan oleh pemohon karena dianggap bertentangan dengan UUD 1945, dan karenanya merugikan hak konstitusional yang dimiliki pemohon sebagai warga negara.

Pengujian konstitusional undang-undang terhadap UndangUndang Dasar 1945 (UUD 1945) yang diajukan kepada Mahkamah 
Konstitusi (MK) adalah untuk menilai kesesuaian antara produk hukum yakni undang-undang dengan UUD 1945 yang didasarkan pada norma-norma yang tertulis di dalamnya. ${ }^{9}$ Umumnya, norma dikategorikan menjadi norma umum (algemeen) dan norma individual (individueel) serta norma yang abstrak (abstract) dan norma yang konkret (concrete). Pembedaan antara yang umum dan yang individual didasarkan pada mereka yang terkena aturan norma tersebut (adressat), ditujukan pada orang atau sekolompok orang yang tidak tertentu atau ditujukan kepada orang atau sekolompok orang yang tertentu.

Ada dua jenis metode penyelesaian yang dilakukan untuk perkara-perkara ini, yaitu dalam bentuk ketetapan dan keputusan. ${ }^{10}$ Ketetapan merupakan suatu kesimpulan yang bersifat final dan mempunyai kekuatan hukum yang mengikat sejak diucapkan, yang isinya di luar dari substansi permohonan. Misalnya ketetapan tentang Mahkamah Konstitusi tidak berwenang untuk memeriksa permohonan perkara atau tentang penerimaan permohonan pembatalan perkara. Keputusan merupakan suatu kesimpulan yang mempunyai kekuatan hukum yang mengikat sejak diucapkan yang isinya tentang dikabulkan atau ditolaknya permohonan suatu perkara.

Mahkamah Konstitusi merupakan peradilan tingkat pertama dan terakhir yang putusannya bersifat final dan mengikat. Putusan yang dikeluarkan oleh Mahkamah Konstitusi memiliki dampak yang

\footnotetext{
${ }^{9}$ Mohammad Mahrus Ali, Konstitusionalitas dan Legalitas Norma dalam Pengujian Undang-Undang Terhadap Undang-Undang Dasar 1945, "Jurnal Konstitusi”, Volume 12, Nomor 1, Maret 2015, hal. 175. Hukum acara untuk perkara pengujian undang-undang di Mahkamah Konstitusi ini agak berbeda dibandingkan dengan peradilan biasa, karena hal yang dipertimbangkan dan diperiksa adalah opini dan tafsiran, bukannya pada fakta-fakta, sehingga analisis terhadap data-data menjadi hal yang penting dan utama untuk disajikan.

10 Tri Sulistyowati, "Putusan Mahkamah Konstitusi dalam Judicial Review dan Beberapa Permasalahannya", Jurnal Hukum Prioris, Volume 1, Nomor, September 2006, hal. 18. Baik keputusan, ketetapan, maupun putusan haruslah berisi norma hukum yang berlaku mengikat untuk subyek, ruang, dan waktu tertentu. Karena itu, merujuk kepada teroi Hans Kelsen, biasa dipakai istilah concrete and individual norms, Jimly Asshiddiqie, Hukum Acara Pengujian Undang-Undang,: Konstitusi Press, Jakarta 2006, hal. 279.
} 
sangat luas, bukan hanya bagi para pihak, tetapi juga masyarakat pada umumnya. Putusan MK memperoleh kekuatan hukum tetap sejak selesai diucapkan dalam sidang pleno terbuka untuk umum. ${ }^{11}$

Putusan MK diambil dalam Rapat Permusyawaratan Hakim (RPH) yang dihadiri sekurang-kurangnya 7 (tujuh) orang Hakim dan dibacakan/diucapkan dalam sidang pleno terbuka untuk umum yang dihadiri sekurang-kurangnya 7 (tujuh) orang Hakim. ${ }^{12}$ Amar putusan MK atas permohonan pengujian undang-undang terhadap UndangUndang Dasar Negara Republik Indonesia Tahun 1945 diatur berdasarkan ketentuan Pasal 56 ayat (1), ayat (2), ayat (3) dan ayat (4), serta pasal 57 ayat (1) Undang-Undang Nomor 24 Tahun 2003.13

Putusan Mahkamah Konstitusi atas pengujian undang-undang memperoleh kekuatan hukum tetap sejak selesai diucapkan/dibacakan, sehingga pelaksanaan putusan Mahkamah Konstitusi dilaksanakan sejak selesai dibacakan putusan yang bersangkutan. Meskipun Putusan Mahkamah Konstitusi mempunyai kekuatan hukum mengikat sejak selesai dibacakan, namun tidak semua putusan Mahkamah Konstitusi yang mengabulkan permohonan Pemohon dapat langsung dilaksanakan (excecutable), karena untuk pelaksanaan putusan Mahkamah Konstitusi tersebut masih memerlukan tindak lanjut dengan pembentukan undang-undang baru atau undang-undang perubahan, sehingga jika dilihat dari pelaksanaan putusan Mahkamah Konstitusi atas pengujian undang-undang, maka putusan Mahkamah Konstitusi dibedakan menjadi 2 (dua), yaitu: ${ }^{14}$

\footnotetext{
11 Pasal 47, Undang-Undang Nomor 24 Tahun 2003 tentang Mahkamah Konsitusi.

12 Pasal 31, Peraturan Mahkamah Konstitusi Nomor 06/PMK/2005 tentang Pedoman Beracara dalam Perkara Pengujian Undang-Undang.

13 Ibid., Pasal 36.

14 Inosentius Samsul, Laporan Akhir Pengkajian Hukum Tentang Putusan Mahkamah Konstitusi,: Badan Pembinaan Hukum Nasional, Kementerian Hukum dan HAM RI, 2009, Jakarta, hal. 102.
} 
1. Putusan Mahkamah Konstitusi yang langsung dapat dilaksanakan "excecutable"

2. Putusan Mahkamah Konstitusi yang memerlukan tindak lanjut dengan pembentukan undang-undang atas perubahan undangundang yang bersangkutan. [Putusan MK yang ditindak lanjuti oleh peraturan lain (seperti Perpu perubahan UU Pemilu dan Peraturan KPU, lihat Putusan pengujian UU Pemilu tahun 2004 dan tahun 2008].

Dalam perspektif fungsi checks and balances, 15 maka putusan MK yang merupakan bentuk koreksi terhadap produk lembaga legislatif yang dilaksanakan oleh Presiden dan DPR harus ditindaklanjuti oleh DPR dan Pemerintah melalui penyempurnaan terhadap UU yang dinilai bertentangan dengan UUD 1945 atau yang inkonstitusional. ${ }^{16}$ Namun, dalam prakteknya, terdapat beberapa putusan yang kontroversial, yaitu putusan yang masih menyisahkan keraguan dan menimbulkan polemik publik terhadap isi putusan MK. Faktor ini dapat menjadi pertimbangan DPR dalam menindaklanjuti putusan MK. Faktor ini akan semakin kuat, karena secara de facto DPR dan Pemerintah yang sama-sama telah memberikan persetujuan terhadap lahirnya suatu UU menjadi pihak dalam persidangan menguji UU terhadap UUD 1945. Kehadiran DPR dan Pemerintah dalam memberikan keterangan dalam sidang di MK mengandung substansi pembelaan terhadap UU yang dibuatnya sendiri. Oleh karena itu, pihak DPR secara psiko politik masih belum siap dalam waktu yang cepat

15 Unsur checks and balances sebagai implementasi pemisahan kekuasaan, agar kewenangan lembaga negara tidak menimbulkan kekacauan dalam wujud negara hukum dan kepentingan rakyat banyak. Lihat, Indra Rahmatullah, "Rejuvinasi Sistem Checks And Balances dalam Sistem Ketatanegaraan Di Indonesia", Jurnal Cita Hukum. Vol. I, No. 2, Desember 2013, hal. 217

16 Kekuasaan kehakiman yang dilakukan oleh Mahkamah Konstitusi berasal dan UUD 1945, dan menjadi penyeimbang terhadap keputusan-keputusan DPR serta tindakantindakan yang dilakukan oleh pemerintah. Tentu saja pelaksanaan fungsi dan wewenang Mahkamah Konstitusi akan sangat bergantung sejauh mana tingkat independensinya. Lihat, url: https://mkri.id/index.php?page=web.Berita\&id=11779, diakses pada tgl 23 April 2019 
untuk memproses agenda legislative review terhadap UU yang dinyatakan bertentangan dengan UUD $1945 .{ }^{17}$

\section{B. Implikasi Putusan 36/PUU-XV/2017 tentang Permohonan Hak Angket DPR}

Banyak permasalahan yang justru muncul pasca dibacakannya putusan Mahkamah Konstitusi. Beberapa masalah yang muncul tersebut antara lain adalah: 18

1. Adanya kekosongan hukum pasca putusan

2. Konsistensi putusan Mahkamah Konstitusi.

3. Koherensi antara pertimbangan hukum dengan amar putusan.

4. Tidak adanya sanksi yang dapat diterapkan untuk memastikan kepatuhan para pihak terhadap putusan Mahkamah Konstitusi.

Pada kenyataannya, para pihak yang berkepentingan tidak selalu patuh pada putusan Mahkamah Konstitusi. Sebagai contoh adalah penerbitan Perpres No.55 Tahun 2005 tentang Harga Jual Eceran Bahan Bakar Minyak Dalam Negeri yang tidak memperhatikan putusan Mahkamah Konstitusi yang menyatakan beberapa ketentuan dalam UU No.22 tahun 2001 tentang Minyak dan Gas Bumi. Kasus ini sempat menyebabkan Ketua Mahkamah Konstitusi mengirimkan surat kepada Presiden RI yang mengingatkan bahwa penerbitan Perpres tersebut seharusnya memperhatikan putusan Mahkamah Konstitusi. Namun demikian, pada kenyataannya Perpres tersebut sampai saat ini masih berlaku.

Majelis hakim konstitusi hanya menyebut "kecuali pelaksanaan tugas dan kewenangan yudisial," yang tidak dielaborasi lebih lanjut. Misal dalam kasus konkret alasan DPR mengadakan angket adalah ketidakmauan Komisi Pemberantasan Korupsi membuka rekaman pemeriksaan MSH, padahal secara jelas Komisi Pemberantasan Korupsi

\footnotetext{
17 Inosentius Samsul, hal. 64.

18 Tri Sulistyowati, Putusan Mahkamah Konstitusi dalam Judicial Review dan Beberapa Permasalahannya, hal. 27.
} 
mengatakan hal tersebut merupakan bagian dari proses penegakan hukum pro justicia. Akibat tidak adanya elaborasi lebih lanjut terhadap bagaimana membatasi hak angket tersebut, maka penggunaan hak angket akan sangat mungkin dilakukan secara eksesif yang dapat berupa lembaga negara maupun materi yang menjadi objek hak angket.

Dalam konteks kelembagaan negara, penggunaan hak angket yang eksesif dapat merambah lembaga negara yang bukan bagian dari eksekutif. Misalnya saja Mahkamah Agung dan Mahkamah Konstitusi sebagai pemegang kekuasaan yudikatif, yang menurut UUD NRI 1945 adalah kekuasaan kehakiman yang merdeka. Hal tersebut misalnya disebutkan oleh Yusril Ihza Mahendra saat memberikan keterangan kepada Panitia Angket dengan mengatakan bahwa semua lembaga dapat menjadi objek hak angket Dewan Perwakilan Rakyat, tidak hanya Komisi Pemberantasan Korupsi, karena hak angket menjadi semacam kontrol terhadap lembaga-lembaga negara termasuk di dalamnya Mahkamah Agung, dengan batas-batas tertentu. Batasannya adalah angket tidak dapat digunakan jika alasannya terkait dengan materi perkara yang ditangani Mahkamah Agung, tetapi dapat digunakan jika ada dugaan suap dalam urusan suatu perkara di Mahkamah Agung. ${ }^{19}$

Berkaitan dengan Putusan MK Nomor 36/PUU-XV/2017 adalah kemungkinan di masa yang akan datang, jika DPR mengambil keputusan untuk mempergunakan hak angket terhadap KPK kembali, maka KPK tidak dapat menolak untuk hadir dalam persidangan hak angket DPR, apalagi hanya dengan alasan independensinya. Karena itu, pada implikasi kedua ini, penggunaan hak angket DPR akan dapat mempengaruhi independensi KPK dalam melakukan pemberantasan

${ }_{19}$ Novianti, "Implikasi Putusan MK atas Penggunaan Hak Angket DPR terhadap KPK", Info Singkat DPR, Vol. X, No. 4, Februari 2018, hal. 4. 
korupsi. Hal tersebut tentunya tidak baik. Apalagi jika mengambil contoh penggunaan hak angket DPR terhadap KPK pada tahun 2017, dimana terlihat ada kepentingan politik tertentu bahkan potensi konflik kepentingan, mengingat banyak kaum politik kenamaan lebih khusus anggota DPR, baik yang masih duduk atau sudah undur dari DPR atau Pemerintah, disebut-sebut terlibat dalam perkara korupsi yang sedang ditangani oleh KPK. Sangat dimungkinkan penggunaan hak angket DPR terhadap KPK untuk melakukan tekanan politik terhadap KPK baik secara kelembagaan maupun individu, sehingga dapat mengganggu pemberantasan korupsi itu sendiri. ${ }^{20}$ Secara hukum, motif politik tersebut tidak dapat dinilai benar-salahnya, kecuali jika dibarengi dengan tindak pidana tertentu, misalnya suap. Motif politik apapun yang dimiliki oleh anggota DPR dalam menggunakan hak angket terhadap KPK harus diterima sebagai sebuah kenyataan. Rakyat-lah yang kemudian dapat memberikan penilaian, apakah motif politik tersebut tepat atau tidak.

Hak angket DPR RI kepada KPK memunculkan problem baru, yaitu setelah diteliti baik secara teoritis, yuridis, maupun legitimasi dari publik tidak terdapat pembenaran atas alasan penggunaan hak angket tersebut sebagaimana diuraikan sebelumnya. Oleh karena itu apabila hak angket tetap "dipaksakan" terindikasi adanya perbuatan untuk menghalangi proses penyidikan untuk membongkar kasus mega korupsi e-KTP. Apabila dalam melanjutkan proses pembongkaran kasus korupsi e-KTP KPK merasa terganggu dalam bekerja maka anggota DPR RI dapat dijerat tindakan menghalangi proses penyidikan kasus korupsi e-KTP sebagaimana rumusan Pasal 21 UU Tipikor. Menerut Eddy Os Hiarej, jika KPK menganggap manuver politik DPR

${ }^{20}$ Mei Susanto, "Hak Angket DPR, KPK dan Pemberantasan Korupsi", Jurnal Integritas, Vol. 4, No. 2, Desember 2018, hal. 121. 
RI dengan menyetujui hak angket menghambat dan menghalangi kinerja KPK dalam mengungkap perkara korupsi e-KTP anggota DPR RI dapat dijerat dengan obstruction of justice atau tindakan menghalanghalangi proses penyidikan. ${ }^{21}$

Setidaknya, dari Putusan Mahkamah Konstitusi Nomor 36/PUU-XV/2017 terhadap reformasi kekuasaan kekuasaan kehakiman terdapat tiga implikasi yang perlu dicatatan khusus. Judicial corruption, 22 Salah satu kekawatiran banyak kalangan yang concern terhadap dunia peradilan adalah Putusan MK tersebut akan semakin menyuburkan praktik korupsi dalam proses peradilan (judicial corruption). Dalam bahasa Denny Indrayana, Putusan Nomor 005/PUUIV/2006 akan menumbuh-kembangkan praktik mafia peradilan. Bahkan, muncul juga penilaian bahwa hakim konstitusi tidak jauh berbeda dengan hakim lain (hakim konstitusi juga hakim). Sudah menjadi rahasia umum, dalam penyelesaian sebuah perkara, permainan uang dapat dikatakan terjadi dari hulu sampai ke hilir. Tegasnya, jual-beli hukum sudah mulai terjadi sejak dari proses penyelidikan sampai ke tahap pelaksanaan putusan hakim. Misalnya, dalam tahap penyelidikan dan penyidikan, permainan uang sering mengalahkan logika dan rasa keadilan masyarakat. Banyak kasus yang sudah seharusnya dilimpahkan ke pengadilan, tetapi karena ada permainan uang, kasus tersebut dihentikan penyidikannya. Alasan yang sering dikemukakan, tidak terdapat cukup bukti untuk melimpahkan perkara ke pengadilan. Padahal, dalam proses-proses awal, penyidik sudah menahan tersangka. Logikanya, kalau dilakukan

\footnotetext{
${ }^{21}$ Denny Indrayana, “Mahkamah Mafia Peradilan”, dalam Kompas, 2006, Jakarta, hal..6., dikutip oleh Tim Peneliti Pusat Studi Konstitusi FH Andalas, Perkembangan Pengujian Perundang-Undangan di Mahkamah Konstitusi, hal. 156.

22 Ibid.
} 
penahanan, penyidik sudah punya keyakinan kuat bahwa tersangka memang melakukan tindak pidana.

Menguatnya krisis kepercayaan kepada MK. Dampak lain, timbulnya krisis kepercayaan publik kepada MK. Banyak kalangan menilai, dalam beberapa waktu terakhir, mulai kelihatan putusan semakin menjauhi gagasan pembaruan hukum. Salah satu putusan MK yang mendapat sorotan tajam adalah pernyataan tidak punya kekuatan mengikat sebagian penjelasan Pasal 2 Ayat (1) Undang-Undang Pemberantasan Tindak Pidana Korupsi. Dalam bahasa yang agak sinis, Teten Masduki mengatakan bahwa mulai terlihat kecenderungan MK "membunuh anak-anak reformasi".

Menguatnya wacana untuk meninjau ulang kewenangan MK. Wacana ini dikembangkan oleh sebagian anggota DPR. Berdasarkan hasil penelitian Pusat Studi Hukum dan Kebijakan (2005), banyak catatan atau ketidaksukaan yang nyata dari anggota DPR. ${ }^{23}$ Lebih lanjut, Hak angket KPK menurut Denny Indrayana, telah menabrak beberapa prinsip dasar lalu lintas bernegara yaitu pertama, sebagai badan lain yang berkaitan dengan kekuasaan kehakiman sebagaimana diatur dalam Pasal 24 UUD NRI Tahun 1945, KPK juga diproteksi dengan prinsip kemerdekaan kekuasaan kehakiman. Maka konsekuensinya adalah tugas dan kewenangan KPK terkait korupsi hanya dapat dinilai dan dikontrol melalui proses peradilan. Lembaga di luar yudikatif tidak berwenang bahkan dilarang untuk mengontrol kewenangan KPK dalam menangani kasus. Kedua, angket adalah hak penyelidikan DPR RI terhadap kebijakan pemerintah dalam hal ini

\footnotetext{
23 Bivitri Susanti, "Hakim atau Legislator: Menyoal Putusan MK tentang Undan-Undang Komisi Yudisial", Makalah disampaikan dalam Diskusi Publik "Putusan MK Nomor 005/PUUIV/2006: Lonceng Kematian Gerakan Antikorupsi?, diadakan oleh Pusat Studi Antikorupsi Fakultas Hukum Universitas Gadjah Mada dan Indonesian Court Monitoring, di Universitas Gadjah Mada, 28 September 2006, hal. 5.
} 
eksekutif baik kementerian maupun nonkementerian. Sedangkan KPK merupakan Komisi Negara independen yang bukan bagian pemerintah sebagaimana diatur dalam Pasal 3 UU KPK. Sehingga menurut Denny Indrayana hak angket dapat dikategorikan sebagai bentuk intervensi DPR RI tehadap KPK dalam menangani kasus mega korupsi e-KTP yang seharusnya independen berdasarkan Pasal 3 UU KPK. ${ }^{24}$

Tindak pidana korupsi sebagai extra ordinary crime sebagaimana diuraikan sebelumnya memberikan dampak terhadap kekuasaan pembentuk perundang-undangan untuk mengatur segala bentuk tindakan korupsi dan perbuatan yang mencoba menghalangi, mencegah, atau menggagalkan proses penegakan hukum pidana korupsi.

Implikasi dari putusan tersebut, dapat dikelompokkan dalam dua hal, yaitu: pertama, implikasi yang bermuatan positif, yaitu penegasan dimilikinya hak angket Dewan Perwakilan Rakyat dalam ketatanegaran Indonesia. Mengapa disebut bermuatan positif, karena dengan adanya putusan tersebut, khususnya dengan melihat pertimbangan majelis hakim (baik yang mayoritas maupun yang menyatakan dissenting opinion) telah mengkonstruksi hak angket sebagai fungsi pengawasan yang melekat pada Dewan Perwakilan Rakyat tanpa harus memperdebatkannya dengan system pemerintahan. Baik dalam sistem parlementer maupun sistem presidensial, hak angket atau hak penyelidikan Dewan Perwakilan Rakyat adalah suatu kelaziman. Kedua, Implikasi yang bermuatan negatif yaitu adanya kemungkinan penggunaan hak angket DPR yang eksesif tanpa memperhatikan batasan-batasan yang ada. Hal tersebut

\footnotetext{
${ }^{24}$ May Lim Charity, Implikasi Hak Angket Dewan Perwakilan Rakyat Republik Indonesia Terhadap Komisi Pemberantasan Korupsi, Jurnal Legislasi Indonesia", Vol. 14, No. 03 - September 2017, hal. 251. KPK adalah lembaga negara independen dan bebas dari intervensi kekuasaan manapun.
} 
dikarenakan majelis hakim konstitusi tidak melakukan konstruksi pembatasan terhadap penggunaan hak angket yang dilakukan oleh Dewan Perwakilan Rakyat, karena terlalu berfokus pada persoalan apakah Komisi Pemberantasan Korupsi dapat dijadikan objek hak angket atau tidak. ${ }^{25}$ Selain dapat menimbulkan pelaksanaan hak angket yang eksesif secara kelembagaan, hak angket yang eksesif juga dapat berkaitan dengan materi yang dijadikan objek hak angket. Dalam perkara hak angket terhadap Komisi Pemberantasan Korupsi misalnya, adalah dikarenakan menolak dan tidak mau membuka rekaman pemeriksaan MSH di Komisi III Dewan Perwakilan Rakyat. Melalui panitia angket, Dewan Perwakilan Rakyat berharap dapat memaksa Komisi Pemberantasan Korupsi untuk dapat membuka rekaman penyidikan tersebut karena kekuatan hak angket adalah dapat memaksa berbagai macam pihak untuk hadir dalam persidangan panitia angket.

Mahkamah Konstitusi sebagai sebuah badan yang dibentuk untuk mewujudkan konsep-konsep hukum yang abstrak, maka Mahkamah Konstitusi harus berjalan sesuai dengan tujuan pembentukan badan tersebut dengan tidak hanya berdasarkan pada konsep abstrak tersebut, tapi mewujudkannya dalam suatu konsep hukum yang progresif. Dalam hal ini progresif akan bertentangan dengan konsep tekstual. Dimana para "penganut" konsep tekstual memandang hukum secara kaku yang hanya didasarkan pada apa yang tertulis dalam teks. Dimana Satjipto Raharjo menyatakan bahwa berhukum melalui teks adalah perbuatan atau tindakan yang secara sadar diproyeksikan kepada latar teks hukum positif. ${ }^{26}$ Konsep ini

${ }^{25}$ Mei Susanto, Hak Angket Sebagai Fungsi Pengawasan Dewan Perwakilan Rakyat: Kajian Putusan Mahkamah Konstitusi Nomor 36/PUU-XV/2017, hal. 401.

26 Satjipto Rahardjo, Hukum dan Perilaku, Jakarta, 2009, hal. 70. 
memang akan menciptakan kepastian hukum, namun cenderung mengesampingkan rasa keadilan dan kemanfaatan, sehingga perlahanlahan mulai ditinggalkan. Dan konsep tersebut sangat bertentangan sekali dengan konsep progresif seperti yang dikemukakan diatas, dimana hukum progresif cenderung menyarankan agar kita berani membuat tusukan dan pembelokan (twist) terhadap sistem yang ada dengan melakukan tindakan intervensi yang nyata (affirmative action). ${ }^{27}$

\section{SIMPULAN}

Putusan Nomor 36/PUU-XV/2017, Mahkamah Konstitusi memutuskan menolak permohonan pemohon yang pada intinya menyebut KPK bukan merupakan objek hak angket DPR. Dengan demikian, putusan tersebut menegaskan KPK merupakan lembaga yang dapat menjadi objek hak angket oleh DPR. Implikasi dari putusan Mahkamah Konstitusi Nomor 36/PUU-XV/2017 tersebut, dapat dikelompokkan dalam dua hal, yaitu: pertama, implikasi yang bermuatan positif, yaitu penegasan dimilikinya hak angket Dewan Perwakilan Rakyat dalam ketatanegaran Indonesia, adanya putusan tersebut, khususnya dengan melihat pertimbangan majelis hakim (baik yang mayoritas maupun yang menyatakan dissenting opinion) telah mengkonstruksi hak angket sebagai fungsi pengawasan yang melekat pada DPR tanpa harus memperdebatkannya dengan sistem pemerintahan. Hak angket atau hak penyelidikan Dewan Perwakilan Rakyat adalah suatu kelaziman. Kedua, Implikasi yang bermuatan negatif yaitu adanya kemungkinan penggunaan hak angket DPR yang eksesif tanpa memperhatikan batasan-batasan yang ada, majelis hakim konstitusi tidak melakukan konstruksi pembatasan terhadap penggunaan hak angket yang dilakukan oleh DPR, karena terlalu berfokus pada persoalan

\footnotetext{
81.

27 Satjipto Rahardjo, Sosiologi Hukum Asai-Esai Terpilih, Genta Publishing, Yogyakarta, 2010, hal.
} 
apakah Komisi Pemberantasan Korupsi dapat dijadikan objek hak angket atau tidak.

\section{DAFTAR PUSTAKA}

\section{Buku}

Asshiddiqie, Jimly, 2006, Pengantar Ilmu Hukum Tata Negara. Jakarta: Konstitusi Press.

--2013, Pengantar Ilmu Hukum Tata Negara. Jakarta:

Rajawali Pers.

--2005, Model-Model Pengujian Konstitusional di Berbagai

Negara. Jakarta: Konstitusi Press.

--2007, Pokok-Pokok Hukum Tata Negara Indonesia-Pasca

Reformasi Jakarta: PT. Bhuana Ilmu Populer (BIP).

2006, Hukum Acara Pengujian Undang-Undang. Jakarta:

Konstitusi Press.

2009, Menuju Negara Hukum yang Demokratis. Jakarta:

Bhuana Ilmu.

Bachtiar, 2015, Problematika Implementasi Putusan Mahkamah Konstitusi pada

Pengujian UU terhadap UUD. Jakarta: Raih Asa Sukses.

Dewa Gede Palguna, I, 2018, Mahkamah Konstitusi Dasar Pemikiran,

Kewenangan, dan Perbandingan dengan Negara Lain. Jakarta:

Konstitusi Press.

Fickar Hadjar, A. 2003, dkk. Pokok-pokok Pikiran dan Rancangan Undangundang Mahkamah Konstitusi. Jakarta: KRHN dan Kemitraan.

Fuady, Munir, 2009, Teori Negara Hukum Modern. Bandung: Aditama, Bandung.

Hardjono, 2009, Legitimasi Perubahan Konstitusi. Yogyakarta: Pustaka Pelajar.

K. Harman, Benny, 2013, Mempertimbangkan Mahkamah Konstitusi. Jakarta: Kepustakaan Populer Gramedia. 
Latif, Abdul, 2009, Fungsi Mahkamah Konstitusi: Upaya Mewujudkan Negara Hukum Demokrasi. Yogyakarta: Total Media.

M Hadjon, Philiphus. dkk., 2011, Pengantar Hokum Administrasi Indonesia. Yogyakarta: Gajahmada University Press.

Mahfud MD, Moh, 2010, Perdebatan Hukum Tata Negara Pasca Amandemen Konstitusi. Jakarta: Raja Grafindo Persada.

Martitah, 2013, Mahkamah Konstitusi. Jakarta: Konstitusi Press.

Rahardjo, Satjipto, 2009, Hukum dan Perilaku. Jakarta: Penerbit Buku Kompas.

Rasyid Thalib, Abdul, 2006, Wewenang Mahkamah Konstitusi dan Implikasinya dalam Sistem Ketatanegaraan Republik Indonesia, PT Citra Aditya Bakti, Bandung.

--2010, Sosiologi Hukum Esai-Esai Terpilih, Genta

Publishing, Yogyakarta.

Samsul, Inosentius, 2009, Laporan Akhir Pengkajian Hukum Tentang Putusan

Mahkamah Konstitusi. Jakarta: Badan Pembinaan Hukum

Nasional, Kementerian Hukum dan HAM RI.

Soemantri, Sri, 1997, Gak Menguji Materiil di Indonesia, Alumni, Bandung.

Soimin, dan Mashuriyanto 2013, Mahkamah Konstitusi dalam Sistem Ketatanegaraan Indonesia, UII Press, Yogyakarta.

Zainal Arifin Hoesein, 2009, Judicial Review di Mahkamah Agung RI, Tiga

Dekade Pengujian Peraturan Perundang-undangan, Raja Grafindo Persada, Jakarta.

\section{Jurnal Ilmiah}

Indra Rahmatullah, Rejuvinasi Sistem Checks And Balances dalam Sistem Ketatanegaraan Di Indonesia, Jurnal Cita Hukum. Vol. I, No. 2, Desember 2013.

Magdalena E. J. Sarkolm, Kewenangan Mahkamah Konstitusi dalam Menguji Undang-Undang Terhadap Undang-Undang Dasar Tahun 1945, 
"Jurnal Lex Administratum",

Vol. III, No. 7, September 2015.

Martitah, 2009, “Judicial Review dan Arah Politik Hukum Nasional:

(Sebuah Perspektif Penegakan Konstitusi)", Jurnal Konstitusi, Vol. I, No. 1.

May Lim Charity, 2017, “Implikasi Hak Angket Dewan Perwakilan Rakyat

RepublikIndonesia Terhadap Komisi Pemberantasan Korupsi", "Jurnal Legislasi Indonesia", Vol. 14, No. 03 - September.

Mei Susanto, 2018, “Hak Angket DPR, KPK dan Pemberantasan Korupsi", Jurnal Integritas, Volume 4 Nomor 2, Desember.

Mei Susanto, 2018, “Hak Angket Sebagai Fungsi Pengawasan Dewan Perwakilan Rakyat: Kajian Putusan Mahkamah Konstitusi Nomor 36/PUU-XV/2017", Jurnal Yudisial, Vol. 11 No. 3 Desember.

Mohammad Mahrus Ali, 2015, “Konstitusionalitas dan Legalitas Norma dalam Pengujian Undang-Undang Terhadap Undang-Undang Dasar 1945”, Jurnal Konstitusi, Vol. 12, Nomor 1, Maret.

Novianti, 2018, “Implikasi Putusan MK atas Penggunaan Hak Angket DPR terhadap KPK", Info Singkat DPR, Vol. X, No. 4, Februari.

Nurul Qamar, 2012, “Kewenangan Judicial Review Mahkamah Konstitusi", Jurnal Konstitusi, Vol. I, No. 1, November.

Sri Darmadi, Nanang, 2015, "Kedudukan Dan Wewenang Mahkamah Konstitusi Dalam Sistem Hukum Ketatanegaraan Indonesia", Jurnal Pembaharuan Hukum, Volume II, No. 2 Mei - Agustus.

Tim Peneliti Pusat Studi Konstitusi FH Andalas, 2010, “Perkembangan Pengujian Perundang-Undangan di Mahkamah Konstitusi", 
Jurnal Konstitusi, Vol. 7, Nomor 6,

Desember.

Tri Sulistyowati, 2006, "Putusan Mahkamah Konstitusi Dalam Judicial

Review Dan Beberapa Permasalahannya", Jurnal Hukum Prioris, Vol. 1, Nomor, September.

Bivitri Susanti, 2006, Hakim atau Legislator: Menyoal Putusan MK tentang Undang-Undang Komisi Yudisial, makalah disampaikan dalam

Diskusi Publik "Putusan MK Nomor 005/PUU-IV/2006:

Lonceng Kematian Gerakan Antikorupsi?, diadakan oleh Pusat

Studi Antikorupsi Fakultas Hukum Universitas Gadjah Mada dan Indonesian Court Monitoring, di Universitas Gadjah Mada.

Denny Indrayana, 2006, "Mahkamah Mafia Peradilan", dalam Kompas,

Jakarta, hal.6., dikutip oleh Tim Peneliti Pusat Studi Konstitusi

FH Andalas, Perkembangan Pengujian Perundang-Undangan di Mahkamah Konstitusi.

Majelis Permusyawaratan Rakyat Republik Indonesia, Undang-Undang Dasar Negara Republik Indonesia 1945 (UUD NRI 1945), Pasal 20A ayat (1) dan ayat (2).

Republik Indonesia, Undang-Undang Nomor 24 Tahun 2003 tentang Mahkamah Konsitusi.

Peraturan Mahkamah Konstitusi Nomor 06/PMK/2005 tentang Pedoman Beracara Dalam Perkara Pengujian Undang-Undang.

Pansus Angket, 2019, hubungan panas KPK \& DPR di 2017", https://www.merdeka.com/peristiwa/pansus-angkethubungan-panas-kpk-dpr-di-2017.html, diakses tanggal 23 April.

Mahkamah Konstitusi Republik Indonesia, 2019, Kedudukan Mahkamah Konstitusi Dalam Struktur Ketatanegaraan Indonesia, https://mkri.id/index.php?page=web.Berita\&id=11779, diakses pada tgl 23 April. 